\title{
Comparing SARS and COVID-19: Challenges of Governance Capacity and Legitimacy
}

\author{
Tom Christensen ${ }^{1,2} \cdot$ Liang $\mathrm{Ma}^{2}$ (B)
}

Accepted: 12 January 2021 / Published online: 2 March 2021

(C) The Author(s), under exclusive licence to Springer Science+Business Media, LLC part of Springer Nature 2021

\begin{abstract}
Governance capacity and legitimacy as two important dimensions in crisis management are crucial for preparing for, making sense of, handling, and learning from crises like epidemics/pandemics. We compare governance capacity and legitimacy of the government in China in response to the SARS and COVID-19 pandemics. Our comparison of the handling processes of two pandemics suggests both positive changes and persistent inertia. Both governance capacity and legitimacy has been improved over time, and there is a tendency that they reinforce each other. Such comparisons help to facilitate learning from the past to be better prepared for the future.
\end{abstract}

Keywords Governance capacity · Governance legitimacy · Crisis management . Reputation management

\section{Introduction}

The COVID-19 outbreak has resulted in 85 million of confirmed infected cases and over 1.85 million of deaths in over 190 countries across the world as of January 5., 2021, and many believe it is on par with the 1918 flu pandemic. However, it is more relevant to compare the COVID-19 pandemic and the SARS pandemic in 2003 because of temporal proximity, similar sources of outbreak, the nature of the viruses, and the responses of governments (Zhang, 2012). Thus, it is meaningful to compare the two cases to see what has changed and what has persisted, primarily pertaining to the handling of the crises and people's reactions to the measures taken.

The SARS pandemic originated in Guangdong province in November 2002, but the outbreak occurred in the spring of 2003. Through a "super-spreader", a doctor who

\section{Liang Ma}

liangma@ruc.edu.cn

1 Department of Political Science, University of Oslo, Oslo, Norway

2 School of Public Administration and Policy, Renmin University of China, Beijing, China 
traveled to Hong Kong from Guangdong and stayed at Hotel Metropol, the virus spread to 23 people at the hotel and further across the world, and was declared a pandemic by WHO (Christensen \& Painter, 2004). From November 1, 2002 to July 1, 2003, 8445 people in 26 countries were infected by SARS, among whom about $80 \%$ of the fatality occurred in mainland China and Hong Kong, and the rest largely in Taiwan, Singapore, and Canada (WHO, 2003).

COVID-19 which started in Wuhan city of Hubei province in China in late November 2019, has both similarities and differences compared with the SARS pandemic. Regarding similarities, COVID-19 shares $80 \%$ of its genome with that of SARS, meaning the two viruses are quite similar, and this type of virus has not been seen since 2003. Control measures in both processes were restrictions on movement, amid the spring break for SARS and the Lunar New Year celebration for COVID-19 (Hale et al., 2020). Like SARS, the Chinese authorities hesitated, for different reasons, to announce the first outbreak of COVID-19, delaying efforts to administer prompt treatment, contain, and fight the virus, which have drawn criticisms from around the world (Ang, 2020). Typical features of both processes seem to have been initial cover-up and denial, followed by partial openness, implementation of strong measures, and insistence on control. The top leaders in both processes in China were in some kind of "double-bind' situation, having to balance between admitting the seriousness and the measures taken, which potentially made the people nervous, and asserting that they have control, becoming exposed to criticisms for deception (Christensen \& Painter, 2004). And, there have been scapegoats in both processes, viz. a central health official and the mayor of Beijing in SARS, and local leaders in Hebei and Wuhan in COVID-19.

In regard to the differences between the two processes, the spread of COVID-19 has been much faster than SARS, involving a lot more people and countries, and has been relatively less deadly (around 1-2\% fatality compared to $9 \%$ for SARS). Initially, COVID-19 was more geographically concentrated and the spread to other countries was much smaller than in SARS, but this pattern changed fundamentally when the virus spread to European countries and the United States. The Chinese health authorities seem to be more prepared for COVID-19 compared to SARS, probably due to learning from the previous virus-handling processes (Baekkeskov \& Rubin, 2017), even though there has also been capacity concerns. COVID-19 is characterized by relatively more draconian measures by the authorities, e.g., sealing off all 13 cities in Hubei, quarantines, roadblocks, restriction on daily movements, extensive measurement of body temperature, restriction on overseas travels, etc. (Tian et al., 2020). Technologies such as big data analytics, cloud computing, and artificial intelligence have been widely used in the containment of COVID-19, and government control has been more precise and efficient than in SARS (Yang, 2020). Social media is of much greater importance for information dissemination under COVID-19 compared to SARS.

In terms of the relationship with the international environment, including WHO, international reactions to China and the measures related to COVID-19 appear to be stronger and more skeptical than in SARS, including advice against travelling to China, reflecting the enormous difference in magnitude. WHO initially did not label the virus a pandemic, and only advised against travelling to Hubei (WHO, 2020). The contact and collaboration between WHO and China have been much closer in COVID-19 than in SARS, to the point that Donald Trump has indicated that it was too cozy and also withdrew US from WHO in July 2020. This also reflects that China was not a big 
player in the international power and business game during SARS, but it is now, with the world much more heavily dependent on its products.

We do not delve into all the similarities and differences between the two processes, and focus mostly on internal crisis features and measures in China, but relate some of them to two important dimensions in crisis management, namely governance capacity and legitimacy. These are crucial for preparing for, making sense of, handling, and learning from crises, like epidemics/pandemics (Christensen et al., 2016). There is a dynamic relationship between governance capacity and legitimacy, especially in large transboundary crises (Ansell et al., 2010). Seen from organization theoretical perspectives (Christensen et al., 2020), governance capacity has primarily something to do with instrumental and structural elements, while governance legitimacy more often deals with cultural and symbolic factors. The focus here is the political-administrative processes, meaning decision-making processes related to the handling of crises by the leadership at different levels (Christensen et al., 2016). Therefore, the study has its combined bases in crisis management theory, organization theory, and governance theory.

The cross-pandemic Chinese focus, instead of a comparative cross-country design, is motivated by two factors. One is the learning factor related primarily to governance capacity, meaning that China used the SARS experience as major impetus for trying to improve the potential for what Lodge and Wegrich (2014) label analytical, coordination, regulatory, and implementation capacity. The other factor is the epicenter argument, meaning that China is where it all started both concerning SARS and COVID-19, which leads to potentially many both academic and practical insights about the handling of the pandemic.

Accordingly, the following research questions were analyzed:

- What characterize the SARS and COVID-19 processes in China with regard to central aspects of governance capacity and legitimacy? What are the main similarities and differences?

- How can the similarities and differences be explained by structural-instrumental, cultural, and symbolic factors, based on organization theory?

The article starts out with discussing some central concepts in crisis management, followed by outlining the concepts of governance capacity and governance legitimacy, and their dynamics. Then follows main comparative trends in the processes and a discussion/conclusion.

\section{The Theoretical Bases}

\section{Crisis and Crisis Management}

Rosenthal et al. $(1989,10)$ defined that a crisis is "a situation in which there is a perceived threat against the core values or life-sustaining functions of a social system that requires urgent remedial action in uncertain circumstances." This makes it necessary for governments to take firm actions (Farazmand, 2014). Crises happen irregularly, which make them different from emergencies and disasters, which often combine normative elements with bad outcomes (Boin, 2008). Crises are not only about 
objective facts, but also have obvious subjective or perceptional elements, as alluded to in the main distinction between capacity and legitimacy. Two central dimensions of crises are often depicted, i.e., the degree of uncertainty and uniqueness, and the degree of transboundary features (Boin et al., 2008). The two virus-handling processes we study score high on both dimensions, even though COVID-19 may have learnt from the SARS process and attained a lower degree of uncertainty, and it appears to be more transboundary.

Crisis management means the processes by which government organizations mitigate, define, handle, and learn from crises (Boin et al., 2008). This deals not only with many instrumental factors, but also a wider context related to the pattern of influence, cultural factors, and reputation management (Wæraas \& Maor, 2015), as well as global factors and relationships with other countries and international organizations, like WHO in our case. By comparing the varying practices across countries and periods of time, it helps to understand, explain, and improve global crisis and emergency management (Farazmand, 2016).

\section{Governance Capacity}

Governance capacity includes formal structural/procedural features and the use of resources, and how these features work in practice (Christensen et al., 2016, 2). Structural or organizational factors, as seen from an instrumental perspective in organization theory, deal with both vertical and horizontal specialization and coordination (Egeberg, 2012). In our case, the vertical elements deals with how much of crisis management is decided centrally and how much delegation of authority occurs, while the horizontal means either specialization in the health sector in handling the virus, or specialization between the health and other relevant sectors. Coordination, whether vertical or horizontal, may deal with both "underlap" and "overlap" (Koop \& Lodge, 2014). Underlap means that no public organizational units really feel responsible, while overlap may lead to inconsistency and conflicts, so the ideal is positive coordination where coherence and increased performance are typical (Bouckaert et al., 2010).

Koop and Lodge (2014) make a distinction between: coordination capacity, meaning bringing diverse public organizations together in joint actions; analytical capacity, meaning having the professional expertise to handle vital information and give assessment and advice; regulation capacity, related to imposing strong regulatory measures when necessary, which in our case related to restrictions on movement, using of space and surveillance; and delivery capacity, meaning handling of the crises, enacting power and providing necessary public services. In the virus-handling processes in China, the ideal is accordingly to further deepen coordinated action, have enough relevant expertise, regulate strongly, and deliver vital public services during the crises.

According to an instrumental perspective on decision-making, like in crisis management, decisions could be taken in two main ways. They can either be taken by the top leaders in some kind of hierarchical command style, or be the result of processes characterized by conflicts, differing interests, negotiations and compromises (March \& Olsen, 1983). One can imagine that a totalitarian one-party system will have crisis management characterized by strong hierarchical command, but a huge and very complex public apparatus, like in China, points more in the direction of heterogeneity, conflicts and transboundary challenges (Christensen \& Ma, 2020). The tensions 
between hierarchy and heterogeneity is seen in the problems in China over the years in establishing one powerful central unit for emergency management. This finally happened in 2018 with the establishment of the Ministry of Emergency Management (MEM). Also, the Chinese Center for Disease Control and Prevention (CCDC) remains a subunit of the National Health Commission (NHC), and is the only sector related to crisis management not incorporated into MEM.

\section{Governance Legitimacy}

Governance legitimacy relates to the degree of cultural support for an organization (Meyer \& Scott, 1983), in our case to crisis management. This support or trust may either be "diffuse", meaning general or encompassing, or "specific", meaning related to certain institutions, leaders, policies, situations, etc. (Easton, 1965). Governance legitimacy deals primarily with the relationship between the government and citizens, called horizontal or societal accountability (Schillemans, 2008), meaning citizens' perception of whether the actions of the authorities are seen as appropriate within certain socially or culturally constructed systems of norms, values and beliefs (Suchman, 1995; Jann, 2016).

Theoretically, this alludes to two strands within institutional theory. First, theories of organizational culture, like the seminal work of Selznick (1957), alluding to mutual adaptation to internal and external pressure, developing a path-dependent culturally appropriateness. Second, neo-institutional theory focusing on how (public) organizations relate to institutional environment and institutional myths in the wider environment (Meyer \& Rowan, 1977). Concerning crisis management, this means how people perceive the actions and symbols used by public executives during and towards the crises influence the degree of legitimacy, from perceptions being self-centered and pragmatic, moral or normative approval or cognitive taken-for-grantedness, but also more collectively related to accepting draconian measures (Christensen et al., 2016).

One essential distinction concerning legitimacy is between input, throughput, and output legitimacy (Scharpf, 1999; Schmidt, 2013). Input legitimacy reflects the degree to which citizens support political processes and parties, as well as how they see the quality of their own participation. Throughput legitimacy deals with processes inside the government apparatus and how open, fair, and impartial they are seen. Output legitimacy deals with policies, means, measures and performance coming out of the public apparatus and directed towards society, and how they are perceived by the citizens.

\section{The Dynamics of Governance Capacity and Legitimacy}

Overall, crisis management performance during the two virus-handling processes are related to the dynamic relationship between governance capacity (to coordinate, analyze, regulate and deliver) and legitimacy (input, throughput and output). Schneider (2011) thinks it is crucial whether it is a "match" or "mismatch" between governmental actions and citizens' expectations. Match means potentially better crisis performance, and mismatch means trouble for the governments' actions. If there is a mismatch, the gap may be narrowed either through strengthening capacity or lowering expectations, the latter related to reputation management (Christensen et al., 2016).

If a government systematically scores high on governance capacity in crisis situations, the likelihood of increased governance legitimacy is there, depending on how 
government is presenting its achievements, and how this resonates with citizens and international stakeholders. If a government is struggling with its capacity, eventually trying to "oversell" itself, the legitimacy may be lower. Seen from governance legitimacy, if government authorities are enjoying high legitimacy, the capacity and performance my increase, as government may need the support and help of citizens and other stakeholders (Rothstein, 1998). But, low legitimacy overall may lead government to struggle with using their potential capacity in crises. Concerning China, which is rather different from the West, people trust the central authorities more than the local authorities (Christensen \& Ma, 2020), so it is important whether their perceptions related to the two virus-handling processes reflect central trust or local distrust.

\section{Methods}

We used the comparative case study method to collect and analyze the data, and the cross-pandemic Chinese focus design is different from the comparative cross-country design. By comparing the Chinese government responses to similar albeit different pandemics in different periods of time (Baekkeskov \& Rubin, 2017), we can control for many endogenous heterogeneities that might not be taken into account in cross-country studies. It is understandable that many aspects of government and the society, particularly the rise of digital governance, has changed substantially from 2003 to 2020, but the bureaucratic routines and inertia in responding to crises and emergencies would sustain with large continuities. Also, a chronicle of the past and present would help to understand how learning and adaptation happened among Chinese bureaucrats.

In comparing the responses of Chinese governments to SARS and COVID-19, we relay on both first- and second-hand materials. We collected government statements of facts and events, media resports, and research reports to chronicle the processes of government responses to the pandemics, which are the main sources of our study during the 2020 global pandemic of COVID-19, which significantly disabled our field work. Given the salience of SARS and COVID-19, uniquious documents and evidence have been accumulated, which give us rich data to explore. Meanwhile, we also used our personal observations and in-depth interviews to support our arguments in this study. One of the authors were in Beijing and Hong Kong during the SARS epidemic, experienced the measures taken close up and wrote an article on the handling of it. The other author was in Beijing during the COVID-19 pandemic, and has been intensively involved in government consultation and media interview about crisis management. These experiences enabled the authors to personally observe and examine the responses of Chinese governments to the two pandemics, which helps to cross-check and triangulate the secondary materials.

\section{Main Features of the Processes}

\section{Governance Capacity}

SARS The cover-up of the source of the virus and initial spreading undermined government capacity to handle the epidemic/pandemic subsequently - early action could have limited the national and international spreading of the virus. The epidemic 
was initially seen more as a threat to political and social stability, causing potential political embarrassment and social unrest, than a public health problem (Thornton, 2009). However, this was subsequently changed to taking draconian measures and mass mobilization of resources. The process along the way was also characterized by confusion and conflicts. There was a high degree of anxiety and uncertainty around SARS, and therefore more risks for the leaders in handling it, undermining government capacity.

The responses of the government were also influenced by the lack of preparedness. First, there was a lack of knowledge about the causes of the virus and its spreading most typically in China, and even international experts admitted that they had limited expertise and there were conflicts over the causes and treatments. Second, in the absence of a cure and well-tried technologies for prevention, the government had to use the trial-and-error approach in the early days of response. Lastly, health authorities did not give clear-cut instructions or offered effective guidance, due to the lack of a sound system of information collection, survival reports and contact tracing (Christensen \& Painter, 2004, 28).

Eventually the government took some draconian measures, including strict quarantines, cancellation of spring holidays and preventing people from leaving Beijing, and building a hospital of 1000 beds in Beijing. WHO had its epidemic surveillance system put in place when SARS started, and reacted based on standard operating procedures (SOPs) and evidence-based medicine, but struggled with adapting to the medical and political system of China. WHO also struggled with getting access to health information from China, but it improved along the way (Schwartz, 2012). International cross-border collaboration picked up speed eventually and WHO played a more central role in the process. It was at the initial stage a limited, but true international crisis, which made the leaders' lack of actions more apparent. The pressure on the society overall and the world resulting from disruptions in production activities and international travels, had potential severe economic impacts, but this aspect was not in the forefront.

The responses were also affected by a lack of horizontal coordination because the military was reluctant to coordinate with the health authorities, as SARS statistics were deemed as military secrets. The mayor of Beijing was sacked, like a central top health official, reflecting leadership factions had to be balanced; local leaders were also sacked.

COVID-19 China scored much higher on governance capacity, and was far more prepared in fighting against COVID-19 than against the SARS epidemic, mainly due to the overhaul of the national emergency management system ( $\mathrm{Lu} \&$ Xue, 2016). Given the lessons from SARS, the government integrated national and local emergency management laws, organs, plans, and mechanisms. In addition, the rapid development and wide use of big data analytics and other emerging technologies equipped the government with strong technological capabilities in monitoring, detecting, and responding to potential risks (Kummitha, 2020). At the local level, the capacity of crisis management was improved as the Military World Games was held in Wuhan in October 2019, and local governments were trained on how to respond to epidemics. 
Early symptoms of the virus were detected in late November 2019, but the whistleblowing of Dr. Li Wenliang and others were suppressed, and government responses were delayed. Their alerts were treated as "disharmonious" voices to the subtle political climate during the local "two sessions" (Provincial People's Congress and People's Political Consultative Conference), which are the local governments' political business cycle (Nie et al., 2013). NHC and CCDC dispatched two groups of experts to check the unknown virus, but their reports were overoptimistic. It was not until January 20, 2020 when Zhong Nanshan, a fellow of Chinese Academy of Sciences, declared in a national TV program that COVID-19 is characterized by human-to-human transmission, that people were widely informed and paid close attention to its spread.

Plans were ready for draconian measures, including quarantines, restriction of movement of people, health controls, etc. The central government set up a senior level steering leadership group to direct the fight against COVID-19, and resources from every corner of the society were quickly mobilized to support the epicenter Wuhan, and Hubei. Wuhan was locked down on January 23, followed by other cities in Hubei. The Spring Festival holidays were extended and people were not allowed to travel across cities. All provinces were required to assist prefectures and counties of Hubei in containing the spread of COVID-19, and one province was to target one city or county. Businesses and nonprofit organizations were very active in delivering medical resources, and they were more efficient and professional than the government in meeting local demands.

It is estimated that the lockdown of Wuhan, social distancing measures, and stringent quarantine mandates decreased interprovincial transmission of COVID-19 and avoided potentially millions of infections and more deaths (Tian et al., 2020). By containing COVID-19 within Wuhan and Hubei, the rest of China was kept safer, which implied that these parts could then return to normality earlier. With nationwide intensive help, Wuhan was able to reopen on April 8, but social distancing measures are maintained to mitigate domestic rebound of the pandemic and inbound spread from other countries.

Different from the reluctance to collaborate with WHO in SARS, the central government was more open and active in sharing and updating WHO with timely information. The WHO Director-General Tedros A. Ghebreyesus visited Beijing on January 28, and the Chinese government promised to increase its donations to WHO. China's practices were highly praised by WHO officials and experts, and some of them were adopted by other countries. China has also helped other countries by sending health personnel and medical equipment.

\section{Governance Legitimacy}

SARS China enjoyed "authoritarian advantages" including "centralized decisionmaking powers, public support, and relations with the mass media" in the SARS pandemic responses (Schwartz, 2012, 315). Despite the initial delay and chaos in responding to the outbreak, the government quickly mobilized the whole country and locked down cities and villages to stem the spread of SARS. Chines people were afraid of SARS, and were willing to follow government instructions to stay at home to keep 
safe. By replacing the minister of health and the mayor of Beijing, the central government retained its public legitimacy.

During the process of SARS, information was not freely flowing. The mainstream media were highly controlled, and were silent and failed to alert the people, which led to the spread of rumors (Ma, 2008). Consequently, people had to resort to seeking information from alternative sources using short message services and internet (Tai \& Sun, 2007). Government officials were ambivalent about truthful information reporting and dissemination (Wan, 2013). On the one hand, they were overconfident in controlling the virus and covered up information to suit their own interests. Also, they did not fully engage with health experts and professionals in decision-making. On the other hand, they were increasingly wary of how dangerous the virus was and the need for action, but they also knew clearly that the outbreak could potentially create fear and resistance at a higher level.

The virus spread quickly to many countries (30 countries in six continents), and developed into a global pandemic. Given the high death rate and the general feeling that it was incurable, WHO eventually recommended draconian measures related to international travel. The containment strategy worked, and SARS was eradicated during about half a year.

COVID-19 The initial responses of local governments in Wuhan city and Hubei province were slow, while citizen trust in the central government remained high (Christensen \& Ma, 2020). An online survey of citizens at the end of January 2020 shows that the central government (8.63 out of 10) enjoyed a much higher level of favor and trust than local governments in Hubei province (5.92) and Wuhan city (5.61). Glocalities survey of citizens also reveals that their trust in the government and civil servants increased after city lockdown and drastic public health measures were imposed.

The National President Xi Jinping closely monitored and directed government responses to COVID-19, and his speeches were widely publicized. First held on February 5, the Press Conference of the Joint Prevention and Control Mechanism of the State Council has been held once or twice every day since then. Key decision-makers of all related ministries and commissions attended to respond to public concerns. Similar press conferences were also organized at the local level to release latest information about COVID-19 and government policies. This must be seen as both trying to be more open and accountable to the public (Schillemans, 2008), and an opportunity to influence through symbols and propaganda.

The leaders are adept at reputation management during COVID-19, which is different from SARS (Wæraas \& Maor, 2015). Additionally, with the help of more extended availability and use of social media (WeChat, Weibo, APP, short-formed videos, livestreaming) government responses and image-building can be more quickly and widely publicized. Government measures in handling COVID-19 received greater acceptance and collective feeling through this. People were more disciplined and understanding of the draconian measures. Nevertheless, since businesses and people suffered heavily from the outbreak of COVID-19, many were eager to know the truth of the initial delay of government responses. Government censorship of social media was heavily criticized by people, and triggered wide outrage concerning Dr. Li 
Wenliang who gave early warnings about the virus and subsequently died, his colleague Dr. Ai Fen who whistle-blew but was obstructed by the hospital authorities, as well as the writer Fang Fang who published Wuhan Diary: Dispatches from a Quarantined City.

\section{Summing up the Main Results}

Table 1 summarizes the comparison between SARS and COVID-19 on different factors of governance capacity and legitimacy. Overall, we found that compared to SARS, government responses to COVID-19 have improved both in terms of governance capacity and legitimacy. More resources, better preparedness and expertise, better coordination and effective draconian measures contributed to this. Additionally, the public was more engaged, willing to make greater sacrifices, and had a more collective interpretation of the crisis.

Overall, the Chinese government appears to score much higher on all aspects of governance capacity, meaning being more prepared and effective in handling COVID19 than SARS, which suggests that the government has learned from the past lessons (Zhang, 2012). In the early containment of the outbreak, the government primarily used non-pharmaceutical public health measures. The WHO-China Joint Mission reached the conclusion that "this truly all-of-Government and all-of-society approach that has been taken in China has averted or at least delayed hundreds of thousands of COVID19 cases in the country... however, has come at great cost and sacrifice by China and its people, in both human and material terms." (WHO, 2020, 17). The governance capacity measures seem to have reinforced each other, meaning better preparedness and expertise help in coordination, regulation and delivery of services (Moorkamp et al., 2020).

First, in regard to the different governance capacity measures, the Chinese central government struggled with coordination capacity measures in a more widespread virus outbreak pattern of SARS, while the geographically concentrated epidemic of COVID19 in Hubei/Wuhan helped in strengthening both vertical and horizontal coordination, primarily in the health sector, which was at the core of the transboundary problem complex (Ansell et al., 2010). After SARS, plans were ready when the coronavirus struck, to be implemented for sending medical personnel from other parts of the country to the epicenter, mobilizing the necessary medical/technical equipment, and building new facilities.

Second, in regard to expertise, meaning analytical capacity (Koop \& Lodge, 2014), the preconditions have improved significantly from the time of SARS to COVID-19. China after SARS has built up very extensive expertise in developing vaccines, including using resources to build up and develop specialized laboratories, making them among the world leading experts in this field. In addition, experiences from SARS made China better equipped to develop epidemiological research on the coupling between government measures and effects on the spreading of the coronavirus. This, together with government officials' increasing involvement of medical professionals and other experts in making decisions on virus handling (Baekkeskov \& Rubin, 2017), have improved both the preparedness and coordination of resources when COVID-19 struck. During SARS, technologies, particularly digital tools, were rather primitive, 


\begin{tabular}{|c|c|c|c|c|c|c|c|}
\hline & 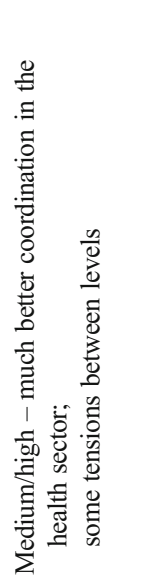 & 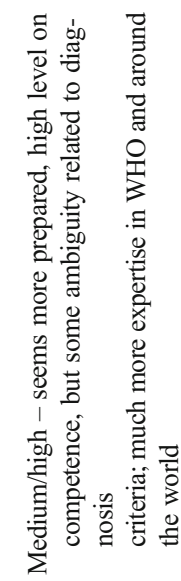 & 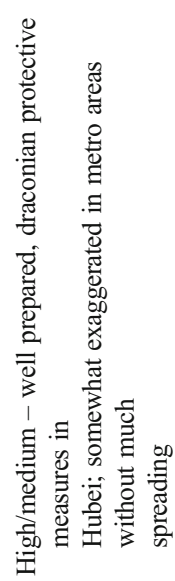 & 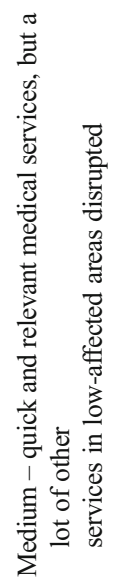 & 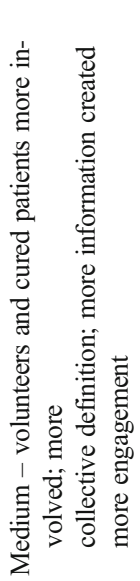 & 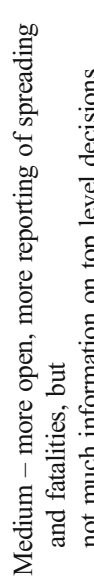 & 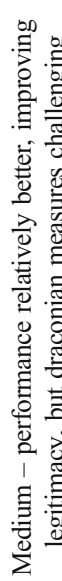 \\
\hline$\stackrel{2}{2}$ & 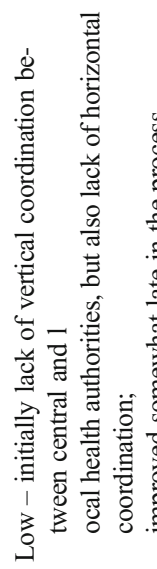 & 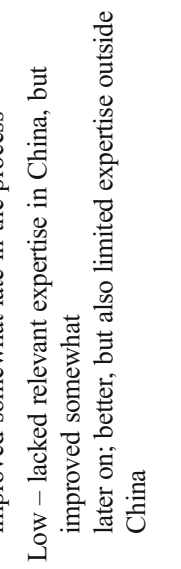 & 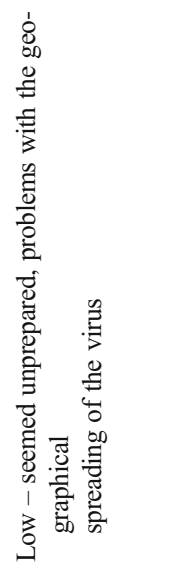 & 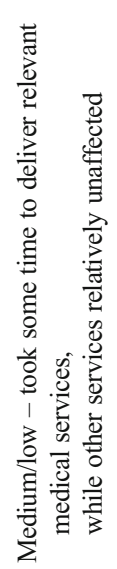 & 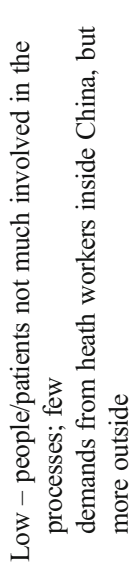 & 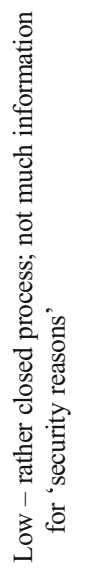 & $\begin{array}{l}\text { F⿱ } \\
1 \\
1 \\
3 \\
3 \\
0\end{array}$ \\
\hline 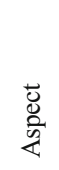 & 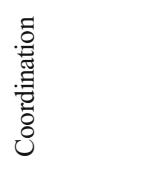 & 胥 & 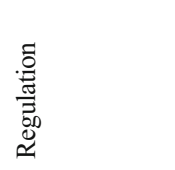 & $\frac{\grave{D}}{\stackrel{2}{0}}$ & 㔽 & 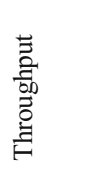 & 总 \\
\hline 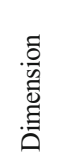 & 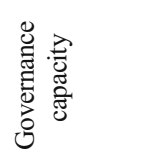 & & & & 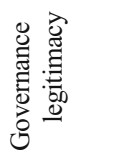 & & \\
\hline
\end{tabular}

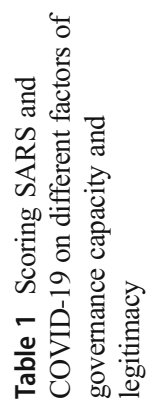


while the use of emerging technologies played an indispensable role in tracing and containing the spread of the coronavirus.

Third, in regard to regulatory capacity, the preconditions were rather problematic during SARS. Due to the wide spreading of the virus in the country, combined with lack of preparedness, regulations were few and weak, which were ineffective in containing the spread of the virus (Christensen \& Painter, 2004, 27). In the case of COVID-19, the regulations pertaining to movement of people were the most draconian, and business and social life overall were restricted. An interesting feature of the regulations was that they affected most parts of China, as some kind of "all-purpose regulation", which was particularly evident in the metro-cities with much less spreading of the virus.

Fourth, concerning delivery capacity, the profile of the two virus-handling processes is different. During SARS, medical and other relevant equipment were mostly lacking, at least in the beginning, while most public and other services were rather unaffected. In the case of COVID-19, it was different in that medical services overall worked rather well, while most other services in the low-affected areas were struggling somewhat more.

With regard to governance legitimacy, both public support of and trust in government have significantly strengthened if we compare COVID-19 with SARS. Strong accountability of local officials during COVID-19 have helped to retain citizen trust in government, (Schillemans, 2008) and the central government has been especially highly trusted. Social media, which were nearly non-existent during SARS, have in COVID-19 both facilitated information dissemination as well as intensified the generation and spread of online rumors. However, the main impression was that the increased information flow was aimed at prompting the Chinese people to follow government instructions about social distancing, handwashing, mask wearing, and home quarantine.

Regarding input legitimacy, people/patients or health workers were not much involved in the SARS process, but that has changed somewhat in the COVID-19 process. The health workers were more vocal, as well as more celebrated, which created a collective feeling. Now the government tried to engage more with volunteers and recovered patients, for a good purpose. Throughput legitimacy is also changing. During SARS, it was a very closed internal process and information was very limited for "security reasons", while the COVID-19 process was in some way more open, in particular regarding information on the spreading of the virus and fatality, but insight into central decision-making was still extremely limited.

In regard to output legitimacy, related to results and effects of performance, the SARS-handling process did not meet expectations, while this has improved in COVID19. Performance is seen as better overall, improving legitimacy, and the propaganda from the central authority, publicly praising its success in fighting the virus and providing assistance to fight against the virus around the world by sending personnel and medical equipment, also helped. However, draconian measures over a long period of time are challenging in terms of legitimacy.

\section{Discussion and Conclusion}

Our main results in comparing the SARS and COVID-19 processes suggest that both governance capacity and legitimacy can be improved over time, and there is a tendency 
that they reinforce each other. Despite early policy inconsistence and chaos, China worked effectively later on (Mei, 2020). Better preparedness, highly improved expertise and increased coordination, together with more transparency and engagement, explain why the COVID-19 process is basically seen as being instrumentally handled in a successful way. The overall improvement of governance capacity and legitimacy is mainly driven by administrative learning and adaptation, which institutionalize governments to be more proactive and responsive in facing similar crises.

The challenges of China's crisis management are also obvious, particularly related to the late admission of the outbreak and the draconian measures in metro-cities with low number of cases. The first challenge has in some ways been turned into a question of national pride, combining cultural and symbolic features, where the official media furthered the view that the world should look up to and thank China, and not criticize it. The cover-up during SARS lasted 3-4 months, which was longer than the period of 44 days in the case of COVID-19. Persistent reluctance to be transparent in early detection is a habit of secrecy and party control as the authoritarian government usually produces two types of information, one for official consumption and the other for public knowledge (Ang, 2020). The sequence of events was the same in the two processes - cover-up, dismissal on grounds that the problem was minor, then admission of the serious nature, imposition of strong measures and then claiming control all the way (Christensen \& Painter, 2004, 27). Overall, the authorities tried to avoid revealing bureaucratic and party failure, and to avoid spreading fear and social unrest.

However, the change in top leadership has effects. Xi Jinping is much more powerful than $\mathrm{Hu}$ Jintao and Wen Jiabao. Xi has been very proactive, visible and personally involved in the organization of emergency management, an engagement that has typical reputation management feature, whether internally or internationally directed (Wæraas \& Maor, 2015). Thanks to the anticorruption campaign since 2012, government integrity and competence have improved. The concerns and mechanisms that led to the cover-up and the eventual revealing of SARS were unlikely to repeated fully in the case of COVID-19, considering that at the very least, increased transparency and citizens' involvement had an impact.

There appeared to be more reluctance to use draconian measures during SARS as it was not easy (if not impossible) to suddenly interrupt normal life due to a geographically deconcentrated virus pattern. However, the government imposed more draconian measures in COVID-19, showing the importance of instrumental features. The Spring Festival holidays provided an ideal window of opportunity to keep people at home. The government also learned from SARS to act proactively and be forward-looking in imposing draconian measures in metro-cities with low number of cases. These draconian measures led to more protective measures being implemented by some countries, which subsequently proved to be successful. Countries which hesitated to follow China in these respects, have ended up with even more stringent measures, enormous capacity problems, and much higher death rates.

In responding to COVID-19, countries vary remarkably in the portfolio of policies (Hale et al., 2020). Drastic measures have worked with painful costs, and some democracies were reluctant to respond early and act decisively. The China Model cannot be replicated in democracies, partly due to ideological preconceptions among Western decision-makers. But, some of the draconian measures in the West have never 
been seen since WWII, so the differences in fighting the coronavirus have not been that large, which is somewhat surprising.

Concerning generalizability and the comparative cross-country aspects, one can further some major arguments. One is that there is a lot of similarities between how China has handled the pandemic and how countries around the world have handled it, concerning for example regulatory measures, even though there are also a lot of differences, reflecting different political systems, cultures, and demographical profiles. Early on, it was argued that the draconic measures used in China could never happen in Western democracies, but soon after one experienced even more draconic measures in some European countries. The Chinese model (or modestly the Chinese solution) might be novel and would not be generalizable to other contexts with different regimes and cultures. It is thus important to conduct more comparative case studies by including other contexts to help us better understand what works and in which contexts. The mechanisms of this and how much of this was imitation and learning from China or other countries coping early in the process, as global learning, should be analyzed in further comparative research (Boin et al., 2020).

A last point is that China's handling of both SARS and COVID-19 shows that crisis management is deeply political processes, in particular related to how to communicate with strong symbols towards the world, so pandemics are an opportunity for reputation management (Wæraas \& Maor, 2015). China has used the opportunity to brag about their own handling and help to other countries. Trump has bashed China as the original epicenter and coupled this to the trade war. COVID-19 was used for manipulating government establishment in Israel and used to decide on emergency laws that seem indefinite in Hungary. So, pandemics are also political in the way that they are choice opportunities to couple diverse political problems and solutions, with symbolic connotations, often in unpredictable ways (Cohen et al., 1972).

What are some of the more general points one can learn from this study? First, good performance potentially adds to legitimacy, both in general and more specifically in crisis management. In our case, this performance was a collaborative effort between government levels. Second, according to the reasoning of Easton's (1965) legitimacy of a general nature, what he calls diffuse support or trust, will benefit performance, or actors' motivation to participate in and support a crisis-handling effort, i.e. it adds what Cyert and March (1963) call "slack". In the handling of COVID-19 this effect is evident, which overcame a more traditional local reluctance to contribute, as seen with SARS. This means that performance, as part of governance capacity may be in a mutual and reinforcing relationship with governance legitimacy, as seen with COVID-19 but not with SARS. So, instrumental and institutional factors are both in play, which extend many crisis management studies that mostly are focused on the instrumental factors (Ansell et al., 2010).

Funding National Natural Sciences Foundation of China (Grant/Award Number: 71774164) and Beijing Office of World Bank Group.

\section{Compliance with Ethical Standards}

Ethical Approval None. 
Informed Consent None.

Conflict of Interest None.

\section{References}

Ang, Y. Y. (2020). When COVID-19 meets centralized, personalized power. Nature Human Behaviour, 4, 445-447. https://doi.org/10.1038/s41562-020-0872-3.

Ansell, C., Boin, A., \& Keller, A. (2010). Managing transboundary crises: Identifying the building blocks of an effective response system. Journal of Contingencies and Crisis Management, 18(4), 195-207. https:// doi.org/10.1111/j.1468-5973.2010.00620.x.

Baekkeskov, E., \& Rubin, O. (2017). Information dilemmas and blame-avoidance strategies: From secrecy to lightning rods in Chinese health crises. Governance, 30(3), 425-443. https://doi.org/10.1111/gove.12244.

Boin, A. (2008). Introduction to crisis management. London: Sage Publications.

Boin, A., McConnell, A., \& Hart, P. T. (Eds.). (2008). Governing after crisis: The politics of investigation, accountability and learning. Cambridge, UK: Cambridge University Press.

Boin, A., Ekengren, M., \& Rhinard, M. (2020). Hiding in plain sight: Conceptualizing the creeping crisis. Risk, Hazards \& Crisis in Public Policy. https://doi.org/10.1002/rhc3.12193.

Bouckaert, G., Peters, B. G., \& Verhoest, K. (2010). The coordination of public sector organizations: Shifting patterns of public management. Hampshire, UK: Palgrave Macmillan.

Christensen, T., \& Ma, L. (2020). Coordination structures and mechanisms for crisis management in China: Challenges of complexity. [journal article]. Public Organization Review, 20(1), 19-36. https://doi.org/10. 1007/s11115-018-0423-9.

Christensen, T., \& Painter, M. (2004). The politics of SARS - rational responses or ambiguity, symbols and Chaos? Policy and Society, 23(2), 18-48. https://doi.org/10.1016/S1449-4035(04)70031-4.

Christensen, T., Lægreid, P., \& Rykkja, L. H. (2016). Organizing for crisis management: Building governance capacity and legitimacy. Public Administration Review, 76(6), 887-897. https://doi.org/10.1111/puar. 12558.

Christensen, T., Lægreid, P., \& Røvik, K. A. (2020). Organization theory and the public sector: Instrument, culture and myth (2nd ed.). London: Routledge.

Cohen, M. D., March, J. G., \& Olsen, J. P. (1972). A garbage can model of organizational choice. Administrative Science Quarterly, 17(1), 1-25.

Cyert, R. M., \& March, J. G. (1963). A behavioral theory of the firm. Englewood Cliffs, NJ: Prentice-Hall.

Easton, D. (1965). The political system: An inquiry into the state of political science. New York: Knopf.

Egeberg, M. (2012). How bureaucratic structure matters: An organizational perspective. In B. G. Peters \& J. Pierre (Eds.), The SAGE handbook of public administration (pp. 157-168). London: Sage Publications.

Farazmand, A. (2014). Crisis and emergency management. In A. Farazmand (Ed.), Crisis and emergency management: Theory and practice (pp. 1-10). New York: Routledge.

Farazmand, A. (2016). Studying crisis and emergency management using global cases of best and worst practices. In A. Farazmand (Ed.), Global cases in best and worst practice in crisis and emergency management (pp. 1-16). Boca Raton, FL: CRC Press.

Hale, T., Petherick, A., Phillips, T., \& Webster, S. (2020). Variation in government responses to COVID-19 Version 9.0. Blavatnik School of Government Working Paper, University of Oxford, Oxford. 10 December 2020. Available: www.bsg.ox.ac.uk/covidtracker.

Jann, W. (2016). Accountability, performance and legitimacy. In T. Christensen \& P. Lægreid (Eds.), The Routledge handbook on accountability and welfare state reforms in Europe. London: Routledge.

Koop, C., \& Lodge, M. (2014). Exploring the co-ordination of economic regulation. Journal of European Public Policy, 21(9), 1311-1329. https://doi.org/10.1080/13501763.2014.923023.

Kummitha, R. K. R. (2020). Smart technologies for fighting pandemics: The techno- and human- driven approaches in controlling the virus transmission. Government Information Quarterly, 37(3), 101481. https://oi.org/10.1016/j.giq.2020.101481.

Lodge, M., \& Wegrich, K. (Eds.). (2014). The problem-solving capacity of the modern state: Governance challenges and administrative capacities. Oxford: Oxford University Press.

Lu, X., \& Xue, L. (2016). Managing the unexpected: Sense-making in the Chinese emergency management system. Public Administration, 94(2), 414-429. https://doi.org/10.1111/padm.12261. 
Ma, R. (2008). Spread of SARS and war-related rumors through new media in China. Communication Quarterly, 56(4), 376-391. https://doi.org/10.1080/01463370802448204.

March, J. G., \& Olsen, J. P. (1983). Organizing political life: What administrative reorganization tells us about government. The American Political Science Review, 77(2), 281-296.

Mei, C. (2020). Policy style, consistency and the effectiveness of the policy mix in China's fight against COVID-19. Policy and Society, 39(3), 309-325. https://doi.org/10.1080/14494035.2020.1787627.

Meyer, J. W., \& Rowan, B. (1977). Institutionalized organizations: Formal structure as myth and ceremony. The American Journal of Sociology, 83(2), 340-363.

Meyer, J. W., \& Scott, W. R. (1983). Centralization and the legitimacy problems of local government. In J. W. Meyer \& W. R. Scott (Eds.), Organizational environments: Ritual and rationality (pp. 199-215). Beverly Hills, CA: Sage Publications.

Moorkamp, M., Torenvlied, R., \& Kramer, E.-H. (2020). Organizational synthesis in transboundary crises: Three principles for managing centralization and coordination in the corona virus crisis response. Journal of Contingencies and Crisis Management, 28(2), 169-172. https://doi.org/10.1111/1468-5973.12294.

Nie, H., Jiang, M., \& Wang, X. (2013). The impact of political cycle: Evidence from coalmine accidents in China. Journal of Comparative Economics, 41(4), 995-1011. https://doi.org/10.1016/j.jce.2013.04.002.

Rosenthal, U., Charles, M. T., \& Hart, P. t. (Eds.). (1989). Coping with crises: The management of disasters, riots, and terrorism. Springfield, IL: Charles C. Thomas.

Rothstein, B. (1998). Just institutions matter: The moral and political logic of the universal welfare state. Cambridge: Cambridge University Press.

Scharpf, F. W. (1999). Governing in Europe: Effective and democratic? Oxford: Oxford University Press.

Schillemans, T. (2008). Accountability in the shadow of hierarchy: The horizontal accountability of agencies. Public Organization Review, 8(2), 175-194.

Schmidt, V. A. (2013). Democracy and legitimacy in the European Union revisited: Input, output and 'throughput'. Political Studies, 61(1), 2-22. https://doi.org/10.1111/j.1467-9248.2012.00962.x.

Schneider, S. K. (2011). Dealing with disaster: Public management in crisis situations (2nd ed.). Armonk, NY: M. E. Sharpe.

Schwartz, J. (2012). Compensating for the 'authoritarian advantage' in crisis response: A comparative case study of SARS pandemic responses in China and Taiwan. Journal of Chinese Political Science, 17(3), 313-331. https://doi.org/10.1007/s11366-012-9204-4.

Selznick, P. (1957). Leadership in administration. New York: Harper \& Row.

Suchman, M. C. (1995). Managing legitimacy: Strategic and institutional approaches. The Academy of Management Review, 20(3), 571-610. https://doi.org/10.2307/258788.

Tai, Z., \& Sun, T. (2007). Media dependencies in a changing media environment: The case of the 2003 SARS epidemic in China. New Media \& Society, 9(6), 987-1009. https://doi.org/10.1177/1461444807082691.

Thornton, P. M. (2009). Crisis and governance: SARS and the resilience of the Chinese body politic. China Journal, 61, 23-48.

Tian, H., Liu, Y., Li, Y., Wu, C.-H., Chen, B., Kraemer, M. U. G., Li, B., Cai, J., Xu, B., Yang, Q., Wang, B., Yang, P., Cui, Y., Song, Y., Zheng, P., Wang, Q., Bjornstad, O. N., Yang, R., Grenfell, B. T., Pybus, O. G., \& Dye, C. (2020). An investigation of transmission control measures during the first 50 days of the COVID-19 epidemic in China. Science, 368(6491), 638-642. https://doi.org/10.1126/science.abb6105.

Wæraas, A., \& Maor, M. (Eds.). (2015). Organizational reputation in the public sector. New York: Routledge.

Wan, R. (2013). Ten years from SARS. Beijing: Wenhuayishu Press.

WHO. (2003). Cumulative number of reported probable cases of SARS from November 1., 2002 to July 1., 2003. Geneva: World Health Organization.

WHO. (2020). Report of the WHO-China joint mission on coronavirus disease 2019 (COVID-19). Geneva: World Health Organization.

Yang, K. (2020). Unprecedented challenges, familiar paradoxes: COVID-19 and governance in a new normal state of risks. Public Administration Review, 80(4), 657-664. https://doi.org/10.1111/puar.13248.

Zhang, H. (2012). What has China learnt from disasters? Evolution of the emergency management system after SARS, southern snowstorm, and Wenchuan earthquake. Journal of Comparative Policy Analysis: Research and Practice, 14(3), 234-244. https://doi.org/10.1080/13876988.2012.687621.

Publisher's Note Springer Nature remains neutral with regard to jurisdictional claims in published maps and institutional affiliations. 
Tom Christensen is Professor Emeritus of Public Administration and Policy at the Department of Political Science, University of Oslo, Norway. His research interests include public organization theory and crisis management.

Liang Ma is Professor at the School of Public Administration and Policy, Renmin University of China, China. His research interests include organizational innovation, performance management, and digital governance. 